\title{
PENGARUH PRETREATMENT JERAMI PADI PADA PRODUKSI ENZIM TERMOSTABIL MENGGUNAKAN ISOLAT BAKTERI TERMOFILIK
}

\section{(The Effect of Rice Straw Pretreatment on Thermostable Enzyme Production Using Thermophilic Bacteria Isolate)}

\author{
Sunrixon Carmando Yuansah ${ }^{1 *}$, Darmawan ${ }^{1)}$, Nurdian Fitriana ${ }^{1)}$, Amran Laga $^{2)}$ \\ ${ }^{1 *}$ Mahasiswa Program Studi Ilmu dan Teknologi Pangan, Fakultas Pertanian, Universitas Hasanuddin, Makassar, \\ Indonesia \\ ${ }^{2)}$ Dosen Program Studi Ilmu dan Teknologi Pangan, Fakultas Pertanian, Universitas Hasanuddin, Makassar, \\ Indonesia
}

*) email Penulis Korespondensi: sunrixoncy@gmail.com

\begin{abstract}
ABSTRAK
Jerami padi merupakan salah satu substrat lignoselulosa yang belum dimanfaatkan secara optimal dan kebanyakan hanya menjadi limbah pertanian apabila tidak ditangani dengan baik. Kandungan selulosa dan hemiselulosa dalam struktur lignoselulosa jerami padi memiliki potensi yang besar untuk produksi enzim termostabil dari bakteri termofilik. Tujuan dari penelitian ini adalah untuk mengetahui pengaruh pretreatment substrat jerami padi terhadap pola pertumbuhan bakteri selulolitik-hemiselulolitik dan aktivitas enzim yang dihasilkan. Metode yang dilakukan dalam penelitian ini meliputi pembuatan tepung jerami, isolasi dan seleksi sistem batch bertingkat, produksi enzim termostabil, pengukuran total bakteri serta pengukuran aktivitas enzim. Hasil yang diperoleh yaitu perlakuan kombinasi delignifikasi basa dan pemanasan uap bertekanan menghasilkan pola pertumbuhan mikroba yang lebih tinggi daripada perlakuan pemanasan uap bertekanan saja. Pengamatan $\mathrm{pH}$ menunjukan penurunan $\mathrm{pH}$ setiap perlakuan. Aktivitas enzim yang diperoleh menunjukan hasil yang fluktuatif akibat adanya fenomena diauksik.
\end{abstract}

Kata Kunci : bakteri, enzim, jerami padi, pretreatment, termostabil.

\section{ABSTRACT}

Rice straw is one of the lignocellulosic substrate that has not been used optimally and mostly just become an agricultural waste if not handled properly. Cellulose and hemicellulose content in lignocellulose structures of rice straw has great potential for thermostable enzymes production from thermophilic bacteria. The purpose of this study were to determine the effect of pretreatment in rice straw substrate on the total number of bacteria and its enzyme activity. The method used in this study include straw flour production, bacteria isolation and multilevel batch selection system, themostable enzyme production, total bacteria and enzyme activity measurement. The results obtained were combination of alkaline delignification and pressurized steam heating treatment resulting higher microbial growth pattern than the pressure steam heating only. Observation of $\mathrm{pH}$ showed $\mathrm{pH}$ decreasing in each treatment. The enzyme activity obtained showed fluctuating results due to the presence of diauxie phenomenon.

Keywords : bacteria, enzyme, pretreatment, rice straw, thermostable.

\section{PENDAHULUAN}

Lignoselulosa merupakan salah satu komponen organik yang menarik banyak perhatian di dunia karena sumberdayanya yang melimpah di alam. Lignoselulosa telah dikembangkan dalam berbagai keperluan seperti produksi bahan bakar dan energi, pakan ternak, produksi bahan kimia hingga bahan pangan (Betts et al., 1991). 
Lignoselulosa banyak menyusun kompleks seluler pada dinding sel tumbuhan dimana lignoselulosa terdiri dari komponen selulosa yang diselubungi oleh hemiselulosa dan lignin (Mussatto \& Teixeira, 2010). Beberapa sumber lignoselulosa berasal dari limbah pertanian seperti jerami padi, bagasse tebu dan tongkol jagung, hasil hutan, rumput gajah dan gandarusa (Kumar et al., 2009). Komposisi dari jerami padi adalah 32,15\% selulosa, 28\% hemiselulosa dan 19,64\% lignin (Shawky et al., 2011). Kandungan selulosa dan hemiselulosa dari jerami padi memiliki potensi pengembangan yang sangat besar apabila dapat dikonversi menjadi produk yang memiliki nilai tambah dan kebaruan. Akan tetapi, untuk mengkonversi komposisi tersebut, pretreatment dan hidrolisis enzimatis dilakukan sebagai salah satu strategi pemanfaatan limbah lignoselulosa.

Proses delignifikasi merupakan usaha yang dilakukan untuk mengubah struktur kimia dari lignoselulosa dengan mendegradasi lignin. Proses ini mengakibatkan ikatan kovalen, hidrogen dan van der Walls pada lignoselulosa terurai sehingga komponen selulosa dan hemiselulosa telepas dari struktur lignoselulosa (Agustini \& Efiyanti, 2015). Delignifikasi dapat dilakukan secara kimia, fisiko-kimia, biologi dan thermal (panas), dimana proses ini dilakukan untuk mengefisienskan kerja enzim dengan memberikan akses lebih mudah terhadap substrat selulosa dan hemiselulosa (Agustini \& Efiyanti, 2015; Rosgaard et al., 2007; Sun \& Cheng, 2002). Pretreatment delignifikasi basa juga memiliki efek untuk meningkatkan tingkat pertumbuhan dan densitas sel maksimal mikroba (Han \& Callihan, 1974).

Kemudahan akses terhadap komponen selulosa dan hemiselulosa dalam substrat lignoselulosa, mengakibatkan bakteri secara simultan mengsekresikan enzim, yang dimana enzim ini akan menghidrolisis komponen selulosa dan hemiselulosa sebagai sumber karbon dalam pertumbuhan bakteri. Pemanfaatan enzim dalam produksi gula fermentasi dari biomassa lignoselulosa menjadi strategi pemanfaatan limbah yang sangat tepat karena lebih ramah lingkungan. Enzim berkerja secara spesifik pada substrat dan tidak menimbulkan hasil samping. Pengembangan pemanfaatan enzim tidak hanya sampai disitu, penggunaan enzim meluas untuk mengoptimalisasi hasil yang didapatkan, salah satunya dengan menggunakan enzim termostabil.

Berdasarkan uraian di atas, tujuan dari penelitian ini adalah untuk mengetahui pengaruh pretreatment substrat jerami padi terhadap pola pertumbuhan bakteri selulolitik-hemiselulolitik dan aktivitas enzim yang dihasilkan.

\section{METODOLOGI PENELITIAN}

\subsection{Alat}

Alat yang digunakan pada penelitian ini yaitu cawan petri (Anumbra), mikropipet (Eppendorf), pipet ukur (Pyrex), autoklaf (Yamato SM-510), Erlenmeyer (Pyrex), hot plate stirrer (Stuart CB302), neraca analitik (Satorius), bulb (Eppendorf), laminar air flow (AdvancedLab ADV 02V), incubator (Quincy Lab Model 10-140), tabung reaksi (Pyrex), waterbath shaker (Julabo SW-22), rak tabung reaksi.

\subsection{Bahan}

Bahan yang digunakan pada penelitian ini yaitu Kertas $\mathrm{pH}(), \mathrm{NaCl}$ (Merck), media GrancuCult ${ }^{\mathrm{TM}}$ Nutrient Agar (Merck), yeast extract (Merck), meat extract (Merck), pepton (Merck), $\mathrm{KH}_{2} \mathrm{PO}_{4}$ (Merck), $\mathrm{MgSO}_{4}$ (Merck), $\mathrm{CaCl}_{2}$ (Merck), $\mathrm{FeCl}_{3}$ (Merck), CMC foodgrade, Titriplex I teknis, $\mathrm{CaCl}_{2} \cdot 2 \mathrm{H}_{2} \mathrm{O}$ (Merck), $\mathrm{MgSO}_{4} \cdot 7 \mathrm{H}_{2} \mathrm{O}$ (Merck), $\mathrm{KCl}$ (Merck), $\mathrm{NH}_{4} \mathrm{Cl}$ (Merck), metionin (Sigma-Aldrich), kasein (Merck), $\mathrm{H}_{3} \mathrm{PO}_{4} \quad 85 \%$ (Merck), $\mathrm{FeCl}_{3}$ (Merck), $\mathrm{MnSO}_{4}$ (Merck), $\mathrm{H}_{3} \mathrm{BO}_{3}$ (Merck), $\mathrm{ZnSO}_{4}$ (Merck), $\mathrm{CoCl}_{2} \cdot 6 \mathrm{H}_{2} \mathrm{O}$ (Merck), $\mathrm{Na}_{2} \mathrm{MoO}_{4}$ (Merck), $\mathrm{CuSO}_{4}$ (Merck), $\mathrm{H}_{2} \mathrm{SO}_{4} \quad 98 \%$ 
(Merck), deionized water (OneMed). CMC (food grade), Fenol (Merck), Glukosa (Merck), dan Asam 3,5-dinitrosalisilat (Merck).

\subsection{Prosedur Penelitian}

\subsubsection{Pembuatan Tepung Jerami}

Bahan jerami padi dipreparasi menjadi potongan dengan ukuran kecil (5$10 \mathrm{~cm})$ kemudian dikeringkan dibawah sinar matahari langsung. Potongan jerami yang telah kering digiling dan diayak hingga diperoleh tepung jerami. Tepung jerami selanjutnya dilakukan proses pretreatment. Proses Pretreatment dilakukan dengan 2 perlakuan, perlakuan pertama tepung jerami ditimbang sebanyak $20 \mathrm{~g}$ dan dilarutkan dengan $\mathrm{NaOH} \quad 1 \mathrm{M}$ sebanyak $200 \mathrm{~mL}$ (rasio 1:2), ke dalam erlenmeyer ukuran $500 \mathrm{~mL}$, dipanaskan dengan uap bertekanan $\left(\mathrm{T}: 121^{\circ} \mathrm{C}, 1 \mathrm{~atm}\right.$, $\mathrm{t}: 30$ menit). Selanjutnya, disaring dan dibilas dengan air hingga pHnya netral. Perlakuan kedua dilakukan dengan cara tepung jerami ditimbang sebanyak $20 \mathrm{~g}$ dan dilarutkan dengan akuades sebanyak 200 $\mathrm{mL}$ (rasio 1:2), ke dalam erlenmeyer ukuran $500 \mathrm{~mL}$, dipanaskan dengan uap bertekanan (T:121 ${ }^{\circ} \mathrm{C}, 1 \mathrm{~atm}, \mathrm{t}: 30$ menit). Bahan hasil perlakuan masing-masing dikeringkan dalam oven blower pada suhu $60^{\circ} \mathrm{C}$ selama 4-5 jam, kemudian digunakan sebagai media pengembangan inokulum dan media produksi enzim dan sakarifikasi.

\subsubsection{Isolasi dan Seleksi Sistem Batch Bertingkat}

Isolat bakteri selulolitikhemiselulolitik termofilik diperoleh pada tumpukan jerami yang mengalami pelapukan pada bagian tengah tumpukan. Isolat bakteri selulolitik-hemiselulolitik termofilik dibiakkan pada media nutrient broth sebelum digunakan pada tahap isolasi dan seleksi. Tahap isolasi dan seleksi dilakukan dengan menginokulasikan $1 \mathrm{~mL}$ isolat bakteri selulolitik-hemiselulolitik termofilik ke dalam $25 \mathrm{~mL}$ medium isolasi sistem batch bertingkat dalam erlenmeyer
$100 \mathrm{~mL}$ dengan komposisi media per 200 $\mathrm{mL}$ yaitu yeast extract $0.4 \mathrm{~g}$, beef extract $0.8 \mathrm{~g}$, pepton $1 \mathrm{~g}, \mathrm{KH}_{2} \mathrm{PO}_{4} 0.2 \mathrm{~g}, \mathrm{MgSO}_{4}$ $0.04 \mathrm{~g}, \mathrm{CaCl}_{2} 0.6 \mathrm{~g}, \mathrm{FeCl}_{3} 0.056 \mathrm{~g}$, dan CMC $1 \mathrm{~g}$ (Azhari et al., 2010) dan diinkubasi selama 48 jam pada suhu $60^{\circ} \mathrm{C}$. Hasil inkubasi kemudian diipipet kembali sebanyak $1 \mathrm{~mL}$ dan diinokulasikan pada medium seleksi yang sama sebanyak $25 \mathrm{~mL}$ dalam erlenmeyer $100 \mathrm{~mL}$ dengan 3 kali tingkatan hingga diperoleh isolat bakteri termofilik. Isolat bakteri selulolitikhemiselulolitik termofilik hasil seleksi kemudian diremajakan pada media agar miring NA (Nutrient Agar) dan disimpan sebelum digunakan pada tahap produksi enzim termostabil.

\subsubsection{Produksi Enzim Termostabil}

Isolat bakteri selulolitikhemiselulolitik termofilik hasil seleksi diinokulasikan sebanyak $1 \mathrm{~mL}$ kedalam 100 $\mathrm{mL}$ medium produksi enzim yang terdiri atas tepung jerami $1 \%$ dan larutan mineral sebagai nutrient tambahan. Larutan mineral dibuat dari $0.1 \mathrm{~g}$ asam nitrilo-3-asetat, 0.05 $\mathrm{g} \mathrm{CaCl}_{2} \cdot 2 \mathrm{H}_{2} \mathrm{O}, 0.1 \mathrm{~g} \mathrm{MgSO}_{4} \cdot 7 \mathrm{H}_{2} \mathrm{O}, 0.01 \mathrm{~g}$ $\mathrm{NaCl}, 0.01 \mathrm{~g} \mathrm{KCl}, 0.3 \mathrm{~g} 2 \mathrm{NH}_{4} \mathrm{Cl}, 0.005 \mathrm{~g}$ metionin, $0.2 \mathrm{~g}$ yeast extract, $0.01 \mathrm{~g}$ asam kasamino, $1.8 \mathrm{~g} \mathrm{H}_{3} \mathrm{PO}_{4} 85 \%$, $1 \mathrm{ml}$ larutan $\mathrm{FeCl}_{3} 0.03 \%$, and $1 \mathrm{ml}$ larutan Nitsch's trace dalam volume 1 L (Rastogi et al., 2010). Medium kemudian difermentasi pada suhu $50^{\circ} \mathrm{C}$ pada kecepatan $150 \mathrm{rpm}$ selama 10 hari. Pengambailan sampel sesuai perlakuan diukur pola pertumbuhan mikroba, pH, dan aktivitas enzim. Enzim hasil produksi dipisahkan dari biomassa dan filtrat secara sentrifugasi pada kecepatan 3000 rpm selama 15 menit.

\subsubsection{Desain Penelitian}

Desain penelitian ini meliputi optimalisasi produksi enzim selulolitikhemiselulotik dari pengaruh pretreatment substrat tepung jerami dengan lama fermentasi, dengan perlakuan (A) pretreatment dan (B) lama fermentasi.

A1 : Delignifikasi (Larutan $\mathrm{NaOH} 1 \mathrm{M}$ ) Sistem Uap Bertekanan 
A2 : Pemanasan Sistem Uap Bertekanan

B : Lama fermentasi selama 10 hari dengan pengambilan sampel setiap 24 jam

\section{HASIL DAN PEMBAHASAN}

\subsection{Pola Pertumbuhan Bakteri}

\section{Pola Pertumbuhan Bakteri}

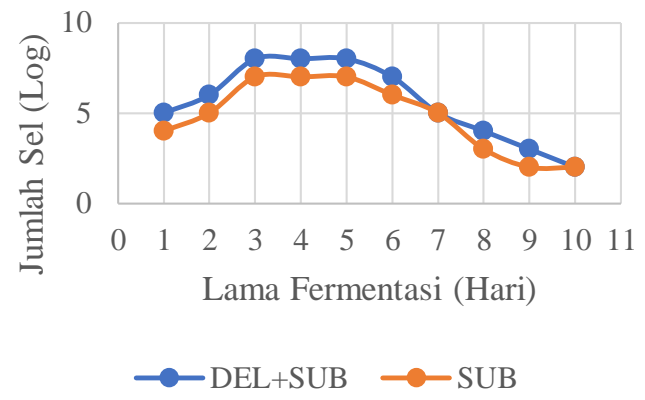

Gambar 01. Pengaruh Pretreatment dan Lama Fermentasi Terhadap Pola

Pertumbuhan Bakteri (a) DEL+SUB = Delignifikasi Basa+Pemanasan Uap Bertekanan), (b) SUB = Pemanasan Uap Bertekanan

Pada Gambar 01 menunjukan bahwa perlakuan pretreatment dan lama fermentasi memiliki pengaruh terhadap pola pertumbuhan bakteri selulolitik dan hemi-selulolitik termofilik yang diinokulasikan ke dalam substrat jerami padi. Perlakuan pretreatment jerami padi dengan kombinasi delignifikasi basa dan pemanasan uap bertekanan (DEL+SUB) memiliki pola pertumbuhan bakteri yang cenderung lebih tinggi daripada perlakuan pemanasan uap bertekanan (SUB). Perbedaan tingkat pertumbuhan bakteri ini dapat disebabkan oleh peningkatan daya cerna (digestibilitas) bakteri terhadap substrat. Menurut Han \& Callihan (1974), pretreatment meningkatkan digestibilitas dari substrat yang ditandai dengan peningkatan jumlah sel dan penurunan konsentrasi substrat tidak larut selama fermentasi. Selain itu, perlakuan delignifikasi basa juga menghilangkan kandungan lignin yang menghambat pertumbuhan bakteri. Jönsson \& Martín
(2016), menyatakan bahwa perlakuan basa dapat menghilangkan lignin dan meningkatkan digestibilitas selulosa. Sedangkan, substrat jerami padi yang diberi perlakuan pemanasan uap bertekanan (SUB) lebih rendah daripada perlakuan kombinasi delignifikasi basa dan pemanasan uap bertekanan (DEL+SUB). Pertumbuhan sel bakteri cenderung lebih lambat pada jerami padi yang diberi perlakuan pemanasan uap bertekanan (SUB) dapat disebabkan karena perlakuan pemanasan uap bertekanan (SUB) hanya membuat sedikit kandungan lignin hilang dan melarutkan kebanyakan kandungan hemiselulosa dari jerami. Kandungan lignin yang tinggi menghambat bakteri untuk dapat menjangkan substrat selulosa dan hemiselulosa sehingga pertumbuhan bakteri menjadi terhambat. Menurut Jönsson \& Martín (2016), proses hidrotermal seperti pemanasan uap bertekanan mengakibat uap air menembus biomassa, menghidrasi selulosa serta menghilangkan kebanyakan kandungan hemiselulosa dan sedikit bagian dari lignin.

Gambar 01 juga menggambarkan pola pertumbuhan bakteri dimana lama fermentasi hari ke-1 sampai hari ke-3 merupakan fase eksponensial, sedangkan pada lama fermentasi hari ke-3 sampai hari ke-5 telah memasuki fase stasioner dan lama fermentasi hari ke-6 dan seterusnya telah memasuki fase kematian.

\section{$3.2 \mathrm{pH}$}

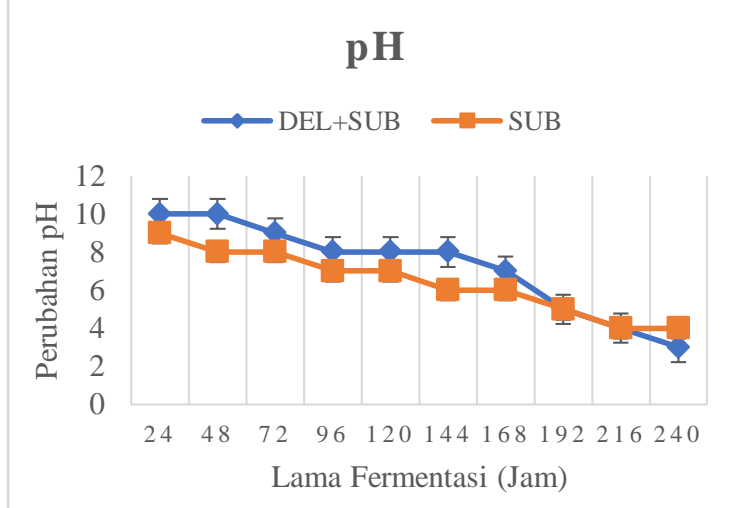

Gambar 02. Pengaruh Lama Fermentasi dan Pretreatment Terhadap Perubahan pH (a) 


\section{DEL+SUB = Delignifikasi Basa + Pemanasan Uap Bertekanan), (b) SUB = Pemanasan Uap Bertekanan}

Lama fermentasi substrat jerami padi akan mempengaruhi $\mathrm{pH}$ media fermentasi. Hal ini ditunjukan pada Gambar 02, dimana $\mathrm{pH}$ mengalami penurunan secara bertahap seiring dengan semakin lamanya proses fermentasi berlangsung. Penurunan $\mathrm{pH}$ yang terjadi disebabkan karena adanya aktivitas metabolisme mikroba yang menghasilkan enzim untuk memecah substrat menjadi gula. Gula yang dihasilkan beberapa dikonversi menjadi asam akibat proses ini. Perlakuan pretreatment yang dilakukan baik dengan kombinasi delignifikasi basa dan pemanasan uap bertekanan (DEL+SUB) serta dengan pemanasan uap bertekanan saja (SUB), mengalami penurunan $\mathrm{pH}$ selama fermentasi berlangsung.

\subsection{Aktivitas Enzim}

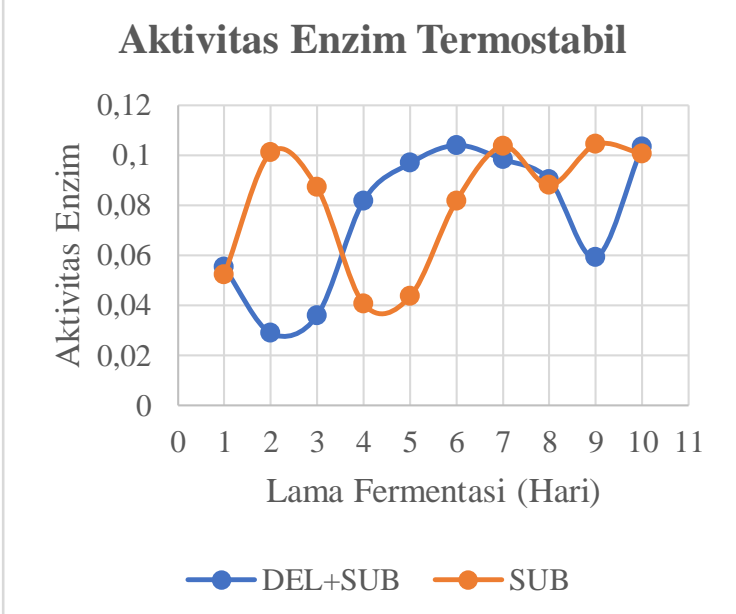

Gambar 03. Pengaruh Pretreatment dan

Lama Fermentasi Terhadap Aktivitas

Enzim (a) DEL+SUB = Delignifikasi

Basa+Pemanasan Uap Bertekanan), (b)

SUB = Pemanasan Uap Bertekanan

Pada Gambar 03 menunjukan bahwa perlakuan pretreatment jerami padi dan lama fermentasi memiliki pengaruh terhadap aktivitas enzim. Pada substrat jerami padi yang diberi perlakuan kombinasi delignifikasi basa dan pemanasan uap bertekanan (DEL+SUB) serta pemanasan uap bertekanan (SUB) saja menghasilkan data yang fluktiatif. Hal ini dapat terjadi karena adanya fenomena diauksik. Fenomena diauksik merupakan fenomena dimana ketika terdapat dua sumber karbon yang dimana keberadaan sumber karbon satu mengakibatkan peningkatan pertumbuhan sel dan aktivitas enzim (Chu dan Barnes 2016; Loomis dan Magasanik 1967).

Pada substrat jerami padi yang diberi perlakuan kombinasi delignifikasi basa dan pemanasan uap bertekanan (DEL+SUB) menunjukan bahwa adanya penurunan aktivitas enzim di awal fermentasi. Hal ini dapat disebabkan karena ketersediaan gulagula sederhana yang dihasilkan dari perlakuan pretreatment ini mengakibatkan penurunan aktivitas enzim. Sedangkan, pada substrat jerami padi yang hanya diberi perlakuan pemanasan uap bertekanan (SUB), menunjukan bahwa terjadi kenaikan aktivitas enzim. Hal ini disebabkan karena pretreatment pemanasan uap bertekanan (SUB) tidak menyediakan sumber karbon yaitu gula sederhana yang cukup sehingga memaksa enzim meningkatkan aktivitasnya memecah substrat kompleks yaitu selulosa dan hemiselulosa untuk memperoleh gula sederhana.

\section{KESIMPULAN}

Perlakuaan pretreatment kombinasi delignifikasi basa dan pemanasan uap bertekanan (DEL+SUB) serta pemanasan uap bertekanan (SUB) memiliki pengaruh terhadap total mikroba dan aktivitas enzim. Pretreatment kombinasi delignifikasi basa dan pemanasan uap bertekanan (DEL+SUB) memiliki pola pertumbuhan mikroba yang lebih tinggi daripada pemanasan uap bertekanan (SUB). Sedangkan pemanasan uap bertekanan memiliki pertumbuhan mikroba yang lebih rendah daripada perlakuan (DEL+SUB) 
karena adanya perbedaan daya cerna (digestibilitas) substrat oleh mikroba.

Perlakuan pemanasan uap bertekanan (SUB) dan perlakuaan kombinasi deliginifikasi basa dan pemanasan uap bertekanan (DEL+SUB) memiliki nilai yang fluktiatif disebabkan fenomena diauksik.

\section{UCAPAN TERIMA KASIH}

Ucapan terima kasih kepada Kementerian Riset, Teknologi dan Pendidikan Tinggi yang telah memberi pendanaan dalam penelitian ini sehingga penelitian ini dapat terselenggara.

\section{DAFTAR PUSTAKA}

Agustini, L., \& Efiyanti, L. (2015). The Effects of Delignification Treatments on Cellulose Hydrolysis and Ethanol Production from Lignocellulosic Wastes. Jurnal Penelitian Hasil Hutan, 33(1), 69-80.

Betts, B., Dart, R. K., Ball, A. S., \& Pedlar, S. L. (1991). Biosythesis and Structure of Lignocelullose. In W. . Betts (Ed.), Biodegradation. London: Springer-Verlag London Limited. https://doi.org/10.1007/978-1-44713470-1

Han, Y. W., \& Callihan, C. D. (1974). Cellulose fermentation: effect of substrate pretreatment on microbial growth. Applied microbiology, 27(1), 159-165. Diambil dari http://www.ncbi.nlm.nih.gov/pubmed /4809907\%0Ahttp://www.pubmedcen tral.nih.gov/articlerender.fcgi?artid=P MC379986

Jönsson, L. J., \& Martín, C. (2016). Pretreatment of lignocellulose: Formation of inhibitory by-products and strategies for minimizing their effects. Bioresource Technology, 199, 103-112.

https://doi.org/10.1016/j.biortech.201 5.10 .009
Kumar, P., Barrett, D. M., Delwiche, M. J., \& Stroeve, P. (2009). Methods for pretreatment of lignocellulosic biomass for efficient hydrolysis and biofuel production. Industrial and Engineering Chemistry Research, 48(8), 3713-3729. https://doi.org/10.1021/ie801542g

Mussatto, S. I., \& Teixeira, J. A. (2010). Lignocellulose as raw material in fermentation processes, 897-907.

Rosgaard, L., Pedersen, S., \& Meyer, A. S. (2007). Comparison of Different Pretreatment Strategies for Enzymatic Hydrolysis of Wheat and Barley Straw Comparison of Different Pretreatment Strategies for Enzymatic Hydrolysis of Wheat and Barley Straw. Appl Biochem Biotechnol, 143, 284-296.

https://doi.org/10.1007/s12010-0078001-6

Shawky, B. T., Mahmoud, M. G., Ghazy, E. A., Asker, M. M. S., \& Ibrahim, G. S. (2011). Enzymatic hydrolysis of rice straw and corn stalks for monosugars production. Journal of Genetic Engineering and Biotechnology, 9(1), 59-63. https://doi.org/10.1016/j.jgeb.2011.05 .001

Sun, Y., \& Cheng, J. (2002). Hydrolysis of lignocellulosic materials for ethanol production : a review q, 83, 1-11. 